\title{
Strategies for Improving Potassium Use Efficiency in Plants
}

\author{
Ryoung Shin*
}

Potassium is a macronutrient that is crucial for healthy plant growth. Potassium availability, however, is often limited in agricultural fields and thus crop yields and quality are reduced. Therefore, improving the efficiency of potassium uptake and transport, as well as its utilization, in plants is important for agricultural sustainability. This review summarizes the current knowledge on the molecular mechanisms involved in potassium uptake and transport in plants, and the molecular response of plants to different levels of potassium availability. Based on this information, four strategies for improving potassium use efficiency in plants are proposed; 1) increased root volume, 2) increasing efficiency of potassium uptake from the soil and translocation in planta, 3) increasing mobility of potassium in soil, and 4) molecular breeding new varieties with greater potassium efficiency through marker assisted selection which will require identification and utilization of potassium associated quantitative trait loci.

\section{INTRODUCTION}

Potassium $\left(\mathrm{K}^{+}\right)$is one of the essential macronutrients that is necessary for plant health and it constitutes up to $10 \%$ of plant dry weight (Adams and Shin, 2014; Leigh and Wyn Jones, 1984; Walker et al., 1996). Potassium plays critical roles in controlling ion homeostasis, osmoregulation, protein metabolism, enzyme activity, membrane polarization, and various metabolic processes (Amtmann et al., 2006; Hastings and Gutknecht, 1978; Schachtman and Shin, 2007; Walker et al., 1996). Additionally, fundamental physiological processes in plants, including photosynthesis, photorespiration, and growth are dramatically affected by $\mathrm{K}^{+}$availability (Gattward et al., 2012; Pettogrew, 2008). Agricultural production in developed countries use fertilizers to increase crop yields and quality, however, excessive usage of fertilizers leads to the leaching of nutrients

RIKEN Center for Sustainable Resource Science, Yokohama 230-0045, Japan

${ }^{*}$ Correspondence: ryoung.shin@ riken.jp

Received 30 May, 2014; accepted 2 June, 2014; published online 18 June, 2014

Keywords: plant, potassium deficient signaling, potassium uptake efficiency, potassium use efficiency from the soil and contributes to environmental pollution, without corresponding increases in yield. In contrast, insufficient fertilizer application in countries where resources are limited results suboptimal yields (Food and Agriculture Organization of the United Nations, 2006). The present review discusses strategies to improve $\mathrm{K}^{+}$use efficiency in plants by understanding the molecular mechanisms involved in $\mathrm{K}^{+}$uptake and transport, as well as the molecular response of plants to different levels of $\mathrm{K}^{+}$ availability.

\section{$\mathrm{K}^{+}$UPTAKE AND TRANSPORT}

$\mathrm{K}^{+}$is the most abundant essential cation in plant cells with an average concentration of approximately $100 \mathrm{mM}$ in the cytosol and 10-200 mM in the vacuole (Leigh and Wyn Jones, 1984; Voelker et al., 2006; Wang and $\mathrm{Wu}, 2013$ ). $\mathrm{K}^{+}$is involved in many aspects of cell physiology and metabolism, including cell expansion, enzyme activation, stomatal opening and turgor pressure maintenance. In order to maintain an appropriate concentration of $\mathrm{K}^{+}$, plant cells monitor $\mathrm{K}^{+}$availability in roots. Although the details of the mechanism that allow plants to sense $\mathrm{K}^{+}$availability and absorb have not been fully elucidated, $\mathrm{K}^{+}$ channels and transporters are considered key players (Adams and Shin, 2014; Amtmann and Blatt, 2009; Fu and Luan, 1998; Gierth et al., 2005; Grabov, 2007; Hastings and Gutknecht, 1978; Leigh and Wyn Jones, 1984; Schachtman and Shin, 2007; Voelker et al., 2006; Wang and Wu, 2013). Higher plants utilize a dual affinity $\mathrm{K}^{+}$uptake system for $\mathrm{K}^{+}$acquisition, depending on $\mathrm{K}^{+}$availability (Epstein et al., 1963). Plants absorb $\mathrm{K}^{+}$via the low affinity $\mathrm{K}^{+}$uptake system, in which shaker type $\mathrm{K}^{+}$ inward rectifying channels play the main role, when $\mathrm{K}^{+}$is sufficient in the soil $(>100 \mu \mathrm{M})$. In Arabidopsis, a shaker type $\mathrm{K}^{+}$ inward rectifying channel, ARABIDOPSIS $\mathrm{K}^{+}$TRANSPORTER1 (AKT1), which is expressed in the plasma membrane of the outer cell layers of roots, plays the major role in the low affinity $\mathrm{K}^{+}$uptake system (Hirsch et al., 1998; Ros et al., 1999; Spalding et al., 1999). Plant $\mathrm{K}^{+}$channels have been reported to form a complex with other $\mathrm{K}^{+}$channels. These complexes serve as the functional subunits of $\mathrm{K}^{+}$channels and each subunit may be able to respond to a wide range of $\mathrm{K}^{+}$conductance (Very and Sentenac, 2003). AKT1 forms a homotetramer and heterotetramer with another $\mathrm{K}^{+}$channel, $\mathrm{KC1}$, and this heteromeric complex acts as a functional subunit. While KC1 alone does not function as a $\mathrm{K}^{+}$inward channel, AKT1 alone can form a functional homocomplex. The AKT1 homomeric complex, how- 
ever, has different features than the AKT1-KC1 complex (Daram et al., 1997; Duby et al., 2008; Geiger et al., 2009; Jeanguenin et al., 2011). The AKT1-KC1 complex is posttranslationally regulated by CALCINEURIN B-LIKE proteins, (CBLs)/CBL-INTERACTING PROTEIN KINASEs (CIPKs), and $\mathrm{N}$-ethylmaleimide-sensitive factor attachment protein receptor (SNARE) proteins (Lan et al., 2011; Ren et al., 2013; Xu et al., 2006).

In contrast to the low affinity $\mathrm{K}^{+}$uptake system, the high affinity $\mathrm{K}^{+}$uptake system is active when external $\mathrm{K}^{+}$availability is low $(<100 \mu \mathrm{M})$ and is comprised of electrochemical potential-driven type transporters (Britto and Kronzucker, 2008; Grabov, 2007; Maathuis and Sanders, 1992). The $\mathrm{H}^{+}: \mathrm{K}^{+}$symporter, $\mathrm{KT} / \mathrm{KUP} / \mathrm{HAK}$ transporters, in higher plants are considered to play a crucial role in high affinity $\mathrm{K}^{+}$transport. Barley HvHAK1 was one of the first KT/KUP/HAK type $\mathrm{K}^{+}$transporters identified in plants. The expression of HvHAK1 transporter is induced by $\mathrm{K}^{+}$starvation and its product functions as a key player in high affinity $\mathrm{K}^{+}$uptake (Santa-Maria et al., 1997). A large number of $\mathrm{KT} / \mathrm{KUP} / \mathrm{HAK}$ transporter genes are generally found in higher plant genomes. There are 13 members in Arabidopsis and 17 members in rice (Banuelos et al., 2002; Rubio et al., 2000) and cluster I type KT/KUP/HAK transporters are also characterized as high affinity $\mathrm{K}^{+}$transporters (Grabov, 2007). Among cluster I transporters, Arabidopsis HAK5 has been the most intensively studied (Gierth et al., 2005; Hong et al., 2013; NievesCordones et al., 2010; Qi et al., 2008). The HAK5 transporter is one of a few KT/KUP/HAK transporter genes whose expression is induced by $\mathrm{K}^{+}$deficiency and decreased when $\mathrm{K}^{+}$is resupplied (Ahn et al., 2004; Qi et al., 2008). KT/KUP/HAK type transporters are different than the shaker type inward $\mathrm{K}^{+}$channels because they cannot readily discriminate ions among the alkali I metal group, such as $\mathrm{Na}^{+}, \mathrm{Rb}^{+}$and $\mathrm{Cs}^{+}$. An even greater distinguishing characteristic is that the high affinity $\mathrm{K}^{+}$transport mediated by $\mathrm{KT} / \mathrm{KUP} / \mathrm{HAK}$ transporters is blocked by ammonium $\left(\mathrm{NH}_{4}^{+}\right)$(Qi et al., 2008; Szczerba et al., 2008). Importantly, $\mathrm{KT} / \mathrm{KUP} / \mathrm{HAK}$ type transporter complexes have not been confirmed in plants. However, various types of higher plant symporters are known to form dimers such as: a nitrate transporter NRT1;1 (Sun et al., 2014; Yong et al., 2010), ABC transporters (Damas et al., 2011), and a sucrose transporter StSUT1 (Liesche et al., 2008). It is therefore possible that KT/KUP/HAK form dimers but this remains to be experimentally determined.

In addition to shaker type $\mathrm{K}^{+}$channels and KT/KUP/HAK type transporters, other membrane proteins have been reported to play a role in $\mathrm{K}^{+}$transport. HIGH-AFFINITY $\mathrm{K}^{+}$TRANSPORTERs (HKTs), $\mathrm{H}^{+}: \mathrm{Na}^{+} / \mathrm{K}^{+}$symporters, which are similar to the TrkH transporter in prokaryotes and the Trk transporter in fungi, are found in all plant species (Corratge-Faillie et al., 2010). The monocotyledons HKTs are involved in $\mathrm{K}^{+}$and $\mathrm{Na}^{+}$uptake but dicotyledons HKTs only function as $\mathrm{Na}^{+}$transporters (Berthomieu et al., 2003; Davenport et al., 2007; Garciadeblas et al., 2003; Horie et al., 2001; 2007). A molecular analysis of HKT transporters has revealed that an amino acid substitution (serine to glycine) in the dicotyledons HKT enables it to conduct $\mathrm{K}^{+}$ (Maser et al., 2002). Tonoplast-localized TANDEM-PORE $\mathrm{K}^{+}$ channels (TPKs, previously known as KCOs family) have also been identified as plant counterparts of animal $\mathrm{KCNK} \mathrm{K}^{+}$channels (Czempinski et al., 1997; 2002; Voelker et al., 2006). Arabidopsis TPK1 has been confirmed to have outward $\mathrm{K}^{+}$channel activity and to be activated by calcium $\left(\mathrm{Ca}^{2+}\right)$ (Czempinski et al., 2002; Voelker et al., 2006).

Plant CYCLIC NUCLEOTIDE-GATED CHANNELs (CNGCs) are nonselective cation channels which bear structural similarity to shaker type $\mathrm{K}^{+}$channels. Some CNGCs have been confirmed to have the ability to transport $\mathrm{K}^{+}$. There are $20 \mathrm{CNGC}$ members in Arabidopsis (Demidchik et al., 2002) and CNGC1, CNGC2, CNGC4, CNGC10 and CNGC18 have been demonstrated to have $\mathrm{K}^{+}$transport activity (Adams and Shin, 2014; Frietsch et al., 2007; Leng et al., 1999; 2002; Ma et al., 2006). Some CATION/ $\mathrm{H}^{+}$EXCHANGERs (CHXs) are involved in $\mathrm{K}^{+}$ uptake and function in osmoregulation and homeostasis (Cellier et al., 2004; Mottaleb et al., 2013; Padmanaban et al., 2007; Zhao et al., 2008). Two Arabidopsis GLUTAMATE RECEPTORs (GLRs), GLR1.1 and GLR1.4, have also been reported to play a role in $\mathrm{K}^{+}$acquisition (Lacombe et al., 2001; Roy et al., 2008; Tapken and Hollmann, 2008).

Once plants absorb $\mathrm{K}^{+}$from the soil via various channels and transporters as described above, there is a need for long distance $\mathrm{K}^{+}$movement so that it can be distributed to the aerial portions of the plant. Various $\mathrm{K}^{+}$channels are also known to be responsible for this process. An Arabidopsis outward rectifying $\mathrm{K}^{+}$channel, STELAR K ${ }^{+}$OUTWARD RECTIFIER (SKOR) plays a key role in $\mathrm{K}^{+}$transport from the outer portion of the root to the xylem, a crucial process for long distance $\mathrm{K}^{+}$movement ( $\mathrm{Liu}$ et al., 2006). $\mathrm{K}^{+}$EFFLUX ANTIPORTERs (KEAs) have been demonstrated to play a role in $\mathrm{K}^{+}$loading into the xylem (Aranda-Sicilia et al., 2012; Yao et al., 1997). Several Arabidopsis shaker type inward rectifying $\mathrm{K}^{+}$channels, including $\mathrm{K}^{+}$ CHANNEL IN ARABIDOPSIS THALIANA1 (KAT1) (Schachtman et al., 1992), KAT2 (Pilot et al., 2001), and AKT2/3 (Cherel et al., 2002; Deeken et al., 2002; Ivashikina et al., 2005), have been experimentally confirmed to function in phloemassociated $\mathrm{K}^{+}$movement.

Intracellular $\mathrm{K}^{+}$movement, such as $\mathrm{K}^{+}$sequestration into vacuoles and $\mathrm{K}^{+}$-mediated guard cell movement, are also regulated by $\mathrm{K}^{+}$channels. $\mathrm{K}^{+}$sequestration into vacuoles may allow plants to absorb additional $\mathrm{K}^{+}$and to help maintain adequate levels of cytosolic $\mathrm{K}^{+}$, thus providing tolerance to upcoming $\mathrm{K}^{+}$deprivation. $\mathrm{N}^{+} / \mathrm{H}^{+}$EXCHANGERs (NHXs) have been shown to be involved in $\mathrm{K}^{+}$and $\mathrm{Na}^{+}$sequestration into vacuoles (Bassil et al., 2012; Gaxiola et al., 1999; Liu et al., 2010; Rodriguez-Rosales et al., 2009). Arabidopsis NHX3 plays a significant role in $\mathrm{K}^{+}$sequestration and is important for establishing low $\mathrm{K}^{+}$tolerance (Liu et al., 2010). The regulation of stomatal opening and closing by the movement of guard cells, which act as gatekeepers for carbon dioxide, is a crucial feature for photosynthesis. The process of guard cells movement is osmotically driven. Activation of $\mathrm{K}^{+}$inward channels, such as the Arabidopsis KAT1 and KAT2 complex (Lebaudy et al., 2010), the rice OsKAT2 and OsKAT3 complex (Hwang et al., 2013a; 2013b), and the Arabidopsis $\mathrm{Ca}^{2+} / \mathrm{H}^{+}$ antiporter, CHX20 (Padmanaban et al., 2007), results in $\mathrm{K}^{+}$influx into guard cells and stomatal opening. In contrast, an Arabidopsis outward rectifying $\mathrm{K}^{+}$channel, GORK, controls stomatal closing through membrane depolarization and $\mathrm{K}^{+}$efflux in an abscisic acid (ABA) dependent manner (Ache et al., 2000; Becker et al., 2003). $\mathrm{K}^{+}$uptake and transport are complex processes that are very interdependent and tightly regulated. To increase crop production, improving $\mathrm{K}^{+}$uptake from the soil and increasing efficiency of $\mathrm{K}^{+}$translocation should have a significant and positive impact. A deeper understanding of the function and regulation of $\mathrm{K}^{+}$transporters and channels will be necessary to improve $\mathrm{K}^{+}$ uptake efficiency in plants.

\section{REGULATION OF $\mathrm{K}^{+}$UPTAKE AND $\mathrm{K}^{+}$DEFICIENT SIGNALING}

In the last decade, the regulatory components of $\mathrm{K}^{+}$sensing 
and signaling have been intensively studied. Even though the phenotypic response to $\mathrm{K}^{+}$deficiency requires a period of time to manifest in plants, a short-term deficiency response occurs within a few hours, leading to the activation of the high affinity $\mathrm{K}^{+}$uptake system (Adams and Shin, 2014; Schachtman and Shin, 2007; Shin and Schachtman, 2004). In Arabidopsis, Reactive Oxygen Species (ROS) produced by NADPH oxidases, plays a critical role in low- $\mathrm{K}^{+}$induced gene expression, as well as the activation of the high affinity $\mathrm{K}^{+}$uptake system within $6 \mathrm{~h}$ after low levels of $\mathrm{K}^{+}$are perceived (Shin and Schachtman, 2004). The expression of Arabidopsis HAK5 is regulated in a ROS dependent manner and the endoplasmic reticulum localized peroxidase, $\mathrm{RCl} 3$, is also involved in low- $\mathrm{K}^{+}$induced $\mathrm{ROS}$ production, as well as HAK5 expression (Kim et al., 2010). Jung et al. (2009) reported that ROS induced by $\mathrm{K}^{+}$deficiency accumulates in the root hair elongation zone in Arabidopsis and modulates low- $\mathrm{K}^{+}$induced root hair elongation. In addition to the response to $\mathrm{K}^{+}$deficiency, ROS is also involved in the response to other macronutrient deficiencies, such as nitrogen $(\mathrm{N})$, phosphate $(\mathrm{P})$, and sulfur (S) (Schachtman and Shin, 2007; Shin et al., 2005). Since low-K $\mathrm{K}^{+}$induced ROS accumulation and HAK5 expression is inhibited in Arabidopsis by compounds that block ethylene, it appears that ethylene is required for low- $\mathrm{K}^{+}$induced ROS accumulation (Jung et al., 2009).

Other phytohormones, such as jasmonic acid, auxin, cytokinin, and ABA, have also been reported to be involved in plant response to $\mathrm{K}^{+}$starvation (Armengaud et al., 2004; 2010; Kim et al., 2009; Nam et al., 2012; Shin et al., 2007). Several genes involved in jasmonic acid biosynthesis are induced by $\mathrm{K}^{+}$starvation (Armengaud et al., 2004), and as a result, the levels of jasmonic acid are increased. Auxin has been shown to modulate lateral root growth under low $\mathrm{K}^{+}$conditions where the levels of free indole-3-acetic acid and the expression of an Arabidopsis R2R3 type MYB transcription factor (MYB77) are dramatically reduced, resulting in a decrease in the number of lateral roots (Shin et al., 2007). There is also additional evidence that auxin is involved in $\mathrm{K}^{+}$signaling. One of the Arabidopsis KT/KUP/HAK proteins, KUP4 has been implicated in auxin transport (Rigas et al., 2001; Vicente-Agullo et al., 2004) and the expression of maize and Arabidopsis $\mathrm{K}^{+}$inward channels is up-regulated by auxin (Philippar et al., 2004; 2006).

Cytokinins are also required for a number of different responses in $\mathrm{K}^{+}$deficiency. Cytokinin levels are reduced under low $\mathrm{K}^{+}$conditions, and cytokinins have been shown to play a role in low- $\mathrm{K}^{+}$induced root hair growth, gene expression, and ROS accumulation (Nam et al., 2012). In contrast to cytokinins, the level of ABA increases under conditions of low $\mathrm{K}^{+}$due to the inactivation of a negative regulator of $A B A$ signaling by the low$\mathrm{K}^{+}$induced nucleus-localized protein, NPX1 (Kim et al., 2009). Additionally, a guard cell-localized $\mathrm{K}^{+}$channel, GORK, is tightly regulated by ABA (Becker et al., 2003) and the activation of an Arabidopsis $\mathrm{K}^{+}$channel, KAT1 requires the phosphorylation by an ABA-activated kinase (Sato et al., 2009). Networks between phytohormones may serve as critical factors in the regulation of $\mathrm{K}^{+}$sensing and signaling and they may be even more complex than described above. The role of these interactive networks and other phytohormones, such as brassinosteroids, gibberellin and strigolactone remains largely unknown.

$\mathrm{Ca}^{2+}$ also plays a key role in $\mathrm{K}^{+}$deficient signaling, as well as in ion homeostasis. Cytosolic $\mathrm{Ca}^{2+}$ levels dramatically increase when plants sense $\mathrm{K}^{+}$starvation, leading to the activation of $\mathrm{K}^{+}$ channels. Elevated levels of $\mathrm{Ca}^{2+}$ induce the formation of $\mathrm{CBL}$ CIPK complexes that phosphorylate their target proteins such as AKT1 (Amtmann and Armengaud, 2007; Lan et al., 2011;
Luan et al., 2009; Wang and Wu, 2013). CBL1 and CBL9 form a complex with CIPK23, which then phosphorylates and activates AKT1, resulting in enhanced $\mathrm{K}^{+}$uptake (Lan et al., 2011; $\mathrm{Xu}$ et al., 2006). In other examples, the CBL4-CIPK6 complex has been shown to regulate AKT2/3-mediated $\mathrm{K}^{+}$currents (Held et al., 2011), and CBL3-CIPK9 has been demonstrated to control $\mathrm{K}^{+}$homeostasis (Liu et al., 2013). The various combinations of CBLs-CIPKs may be able to control diverse biological processes since Arabidopsis has ten CBL proteins (Kudla et al., 1999) and at least 25 CIPKs (Luan et al., 2009). More examples of complexities in the regulation of $\mathrm{K}^{+}$channels are also provided by the interaction of $\mathrm{K}^{+}$channels with PROTEIN PHOSPHATASE 2C (PP2C) (Cherel et al., 2002; Lan et al., 2011) and SNARE proteins (Honsbein et al., 2009). PP2Cs directly interact with the kinase domain of CIPK in the CBLCIPK complex and dephosphorylate CIPK, resulting in the inactivation of AKT1 (Cherel et al., 2002; Lan et al., 2011). SNARE proteins have been known to play a role in the vesicle trafficking that occurs in response to various biotic stresses (Collins et al., 2003; Pajonk et al., 2008), and to bind to ion channels (Leung et al., 2007; Leyman et al., 1999; Sokolovski et al., 2008; Sutter et al., 2006; 2007). An Arabidopsis SNARE protein SYP121, is involved in AKT1 regulation through selective binding to KC1 (Honsbein et al., 2009).

In addition to phosphorylation/dephosphorylation, many $\mathrm{K}^{+}$ channels are regulated by their interaction with other proteins, such as 14-3-3 proteins (Latz et al., 2007; Rajan et al., 2002; Sottocornola et al., 2006; 2008; Xu and Shi, 2006). A variety of biological processes are modulated by $14-3-3$ proteins via their interaction with phosphorylated target proteins (Oecking and Jaspert, 2009; Roberts, 2003). $\mathrm{K}^{+}$currents in Arabidopsis mediated by KAT1 and TPK $1 \mathrm{~K}^{+}$channels are enhanced by their interaction with 14-3-3 proteins (Latz et al., 2007; Sottocornola et al., 2006). Additionally, some isoforms of 14-3-3 are transcriptionally induced by $\mathrm{K}^{+}$deficiency (Shin et al., 2011; Xu and Shi, 2006). It is speculated that many more regulatory components are also involved in the regulation of $\mathrm{K}^{+}$channels and $\mathrm{K}^{+}$ deficient signaling. Interaction between these components is an important component of the regulatory system. Further understanding of the regulatory mechanisms would provide greater opportunities for controlling $\mathrm{K}^{+}$uptake and transport.

\section{INTERACTION WITH OTHER STRESS RESPONSES}

Many authors have reviewed the subject of the interaction between the regulation of $\mathrm{K}^{+}$and other macronutrients (Amtmann and Blatt, 2009; Amtmann et al., 2006; Schachtman and Shin, 2007; Wang and Wu, 2010; 2013). Amtmann and Armengaud (2009) summarized how various metabolites and enzymes are affected by the availability of different macronutrients. Limited $\mathrm{N}$, $\mathrm{P}, \mathrm{K}$ and $\mathrm{S}$ result in a reduction in photosynthesis and alterations in amino acid biosynthesis and enzyme activity. Malate, glucosinolate, nitrate, glutamate, polyamine, and 2-oxoglutarate are all affected by deficiencies of various macronutrients, including $\mathrm{K}^{+}$ deficiency (Amtmann and Armengaud, 2009). The activity of pyruvate kinase is very sensitive to $\mathrm{K}^{+}$availability (GuerreroMendiola et al., 2009; Oria-Hernandez et al., 2005; 2006; Ramirez-Silva and Oria-Hernandez, 2003; Ramirez-Silva et al., 1993; 2001). The level of phosphoenolpyruvate metabolized by pyruvate kinase is also altered by $P$ starvation (Morcuende et al., 2007). The transcriptional regulation of macronutrient deficiency responsive genes and nutrient transporters represent an additional complexity to these interactive networks. ROS levels are increased by N, P, K and S starvation (Morcuende et al., 2007; 


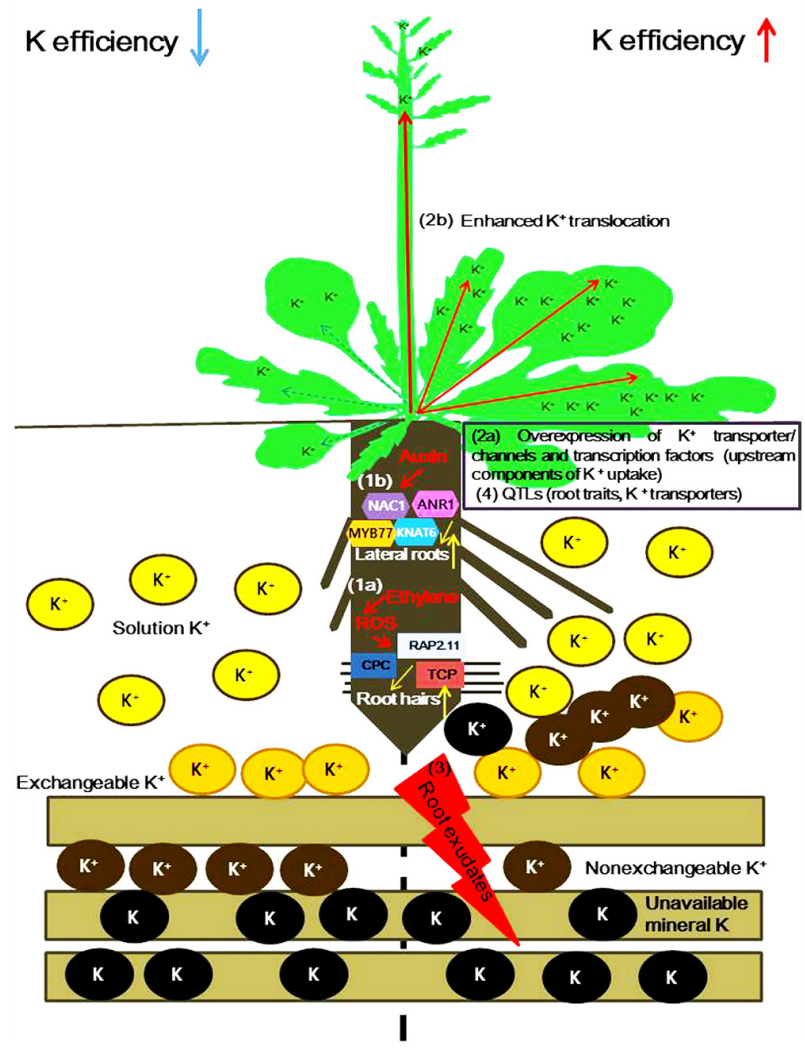

Fig. 1. Strategies for improving the efficiency of $\mathrm{K}^{+}$uptake and utilization in plants. Regulating the expression of transcription factors involved in root hair (1a) and lateral root (1b) development could increase the root volume that is in contact with soil solution, thus providing increased access to $\mathrm{K}^{+}$. Overexpression of genes regulating $\mathrm{K}^{+}$uptake $(2 \mathrm{a})$ and $\mathrm{K}^{+}$translocation in planta $(2 \mathrm{~b})$ could increase $\mathrm{K}^{+}$accumulation in plants. Increased production of root exudates containing organic acids whose activity releases $\mathrm{K}^{+}$into the soil solution could enhance $\mathrm{K}^{+}$mobility (3). The use of $\mathrm{K}^{+}$-associated QTLs in molecular breeding programs could be used for the development on new cultivars with higher $\mathrm{K}^{+}$use efficiency (4).

Schachtman and Shin, 2007; Shin and Schachtman, 2004; Shin et al., 2005) and ROS plays a pivotal role in the transcriptional regulation of many genes responding to nutrient deprivation, including HAK5 (Amtmann and Blatt, 2009; Jung et al., 2009; Shin and Schachtman, 2004). Several transcription factors are also affected by deficiencies in various macronutrients (Hong et al., 2013; Shin, 2011). The nitrate transporter, NRT1.1, a dualmode transporter, is phosphorylated on threonine101 under low nitrate conditions by CIPK23 which is a key regulator of AKT1. When NRT1.1 is phosphorylated on threonine101 by CIPK23, it functions as a high affinity nitrate transporter but dephosphorylation of NRT1.1 leads to switching it to a low affinity nitrate transporter (Ho et al., 2009; Tsay et al., 2011). Even though it is still unclear how CIPK23 regulates both NRT1.1 and ATK1, it appears that CIPK23 may work as a coordinator of $\mathrm{K}^{+}$and nitrate uptake. The majority of the components involved in interaction between the different networks that respond to nutrient deficiencies are still obscure. Understanding the interaction between the molecular operation and regulation of different macronutrient systems in plants will help to improve crop production and the efficient use of fertilizers.

$\mathrm{K}^{+}$also functions as a regulator of biotic stress response. Several reports demonstrated that $\mathrm{K}^{+}$limitation affects plant response to pathogen infection (Holzmueller et al., 2007; Sarwar, 2012; Wang et al., 2013; Williams and Smith, 2001). This also links the positive regulators of pathogen resistance in plants such as ROS, jasmonic acid, and ethylene, to their effects on macronutrient systems and crop productivity. Abiotic stresses, such as drought, cold, and salt stress, are also strongly influenced by $\mathrm{K}^{+}$availability. For example, $\mathrm{K}^{+}$deficiency has a negative impact on drought tolerance (Cakmak, 2005). Plant response to $\mathrm{K}^{+}$deficiency and abiotic stresses, especially salt stress and drought stress, are similar to a certain extent. Abiotic stress and $\mathrm{K}^{+}$deficiency restrict plant root growth and increase the production of ROS and phytohormones (Armengaud et al., 2004; Cakmak, 2005; Schachtman and Shin, 2007; Shi et al., 2013; Wang and Wu, 2013). Most of the early responses (up to $24 \mathrm{~h}$ ) to salt stress and $\mathrm{K}^{+}$starvation are indistinguishable and the induced genes, signaling components, and phytohormones are fairly similar. For example, a nuclear protein X1 (NPX1) which regulates ABA dependent drought stress was originally isolated as a $\mathrm{K}^{+}$deficiency induced gene (Kim et al., 2009). The similarity between the responses to these very different types of stress may be due to a need to maintain osmotic pressure in both stresses. Furthermore, salinity stress is more directly related to $\mathrm{K}^{+}$availability (Shabala and Cuin, 2008). An elevated $\mathrm{Na}^{+}$concentration inhibits $\mathrm{K}^{+}$uptake in plants and induces membrane depolarization which activates outward rectifying $\mathrm{K}^{+}$channels (Shabala and Cuin, 2008; Shabala et al., 2006) and finally results in $\mathrm{K}^{+}$starvation in plants.

\section{STRATEGIES TO IMPROVE $\mathrm{K}^{+}$USE EFFICENCY IN PLANTS}

$\mathrm{K}^{+}$is not metabolized and is one of the most abundant of earth's minerals, comprising approximately $2.5 \%$ of the lithosphere. Although plants can absorb $\mathrm{K}^{+}$from the soil solution, the majority of $\mathrm{K}^{+}$in soil is unavailable, existing in fixed and lattice forms (Ashley et al., 2006; Syers, 1998). In addition to the problem of limited availability of $\mathrm{K}^{+}$, other soil components also interfere with the uptake of $\mathrm{K}^{+}$. For example, higher $\mathrm{NH}_{4}^{+}$and $\mathrm{Na}^{+}$ concentrations interrupt $\mathrm{K}^{+}$uptake by plant roots (Ashley et al., 2006; Qi and Spalding, 2004). Soil moisture also has an influence on the efficiency of $\mathrm{K}^{+}$uptake in plants.

Since $\mathrm{K}^{+}$Availability is one of the important factors regulating cell growth, such as root hair development (Desbrosses et al., 2003; Ivashikina et al., 2001; Rigas et al., 2001) and pollen tube growth (Lu et al., 2011), plants growing under $\mathrm{K}^{+}$-limited conditions are stunted and poorly developed. Plants have at least two mechanisms to adjust and adapt to limited $\mathrm{K}^{+}$in order to survive. When plants perceive a $\mathrm{K}^{+}$shortage, they increase their root volume, which in turn increases the capacity of roots to uptake more $\mathrm{K}^{+}$from the soil. Plants also activate a high-affinity $\mathrm{K}^{+}$uptake system. Once plants cannot make adjustments to increase uptake of $\mathrm{K}^{+}$and redistribution of available $\mathrm{K}^{+}$internally, most likely from the vacuole, because $\mathrm{K}^{+}$is limited; plants slow down their metabolism and eventually stop growing. In order to remedy the problem of reduced yields in agricultural crops due to $\mathrm{K}^{+}$limitation in plants, one could propose to either increase the use of fertilizer or to find a way to improve efficiency of $\mathrm{K}^{+}$uptake, transport and utilization. Based upon our current knowledge, four strategies are suggested for improving $\mathrm{K}^{+}$use efficiency in plants (Fig. 1). 
Increasing root volume to provide greater access to available $\mathrm{K}^{+}$

Twenty-eight hour exposure of Arabidopsis plants to a $\mathrm{K}^{+}$deficient condition leads to increased root hair elongation. This is considered to be an adaptive response to increase the root volume for enhanced access to available $\mathrm{K}^{+}$(Jung et al., 2009). Longer periods of $\mathrm{K}^{+}$starvation, however, results in reduced shoot biomass and both primary and lateral root development (Armengaud et al., 2004; Shin et al., 2007). The increased length of root hairs in response to low $\mathrm{K}^{+}$has also been observed in pea, red clover, alfalfa, barley, rye, ryegrass and rape (Hogh-Jensen and Pedersen, 2003). Therefore, it is likely that plants try to increase root volume in order to cope with low $\mathrm{K}^{+}$in soils. This enhancement of root hair volume could be achieved by overexpressing transcription factors that are directly involved in root hair development. A MYB like transcription factor, CAPRICE (CPC), is a positive regulator of root hair differentiation (Kirik et al., 2004; Schellmann et al., 2002; Wada et al., 2002) and the overexpression of a tomato CPC-like MYB gene (SITRY), under the control of the Arabidopsis CPC promoter in a CPC mutant (cpc-2) of Arabidopsis, has been reported to result in increased numbers of root hairs (Tominaga-Wada et al., 2012). Overexpression of the low $\mathrm{K}^{+}$induced AP2/ERF transcription factor 11 (RAP2.11) also results in enhanced root hair length (Kim et al., 2012). Additionally, overexpression of a cotton bHLH domain containing TCP transcription factor in Arabidopsis also positively regulates root hair initiation and elongation (Hao et al., 2012). Several Arabidopsis transcription factors, including MYB77 (Shin et al., 2007), NO APICAL MERISTEM CUP-SHAPED COTYLEDON1 (NAC1) (Xie et al., 2000), KNOTTED-LIKE ARABIDOPSIS TRANSCRIPTION FACTOR 6 (KNAT6) (Dean et al., 2004), and a MADS box transcription factor (ANR1) (Montiel et al., 2004; Zhang and Forde, 1998), have been demonstrated to be positive regulators of lateral root initiation. Overexpression of these transcription factors under the control of a root specific promoter, or a $\mathrm{K}^{+}$ deficiency inducible promoter such as the Arabidopsis HAK5 promoter (Jung et al., 2009), presents one promising strategy to improve $\mathrm{K}^{+}$uptake efficiency.

Increasing $\mathrm{K}^{+}$uptake efficiency and $\mathrm{K}^{+}$translocation in planta

Enhancing the kinetics of $\mathrm{K}^{+}$uptake is one of the most direct ways to improve $\mathrm{K}^{+}$uptake efficiency. This approach involves activating the components of $\mathrm{K}^{+}$uptake, such as $\mathrm{K}^{+}$transporters, $\mathrm{K}^{+}$channels, $\mathrm{K}^{+}$channel/ transporter interacting proteins, and upstream components. Generally, low $\mathrm{K}^{+}$availability increases the rate of $\mathrm{K}^{+}$uptake. Therefore, constitutive activation of the high affinity $\mathrm{K}^{+}$uptake system even under optimal $\mathrm{K}^{+}$ conditions will help to increase $\mathrm{K}^{+}$uptake. Hong et al. (2013) have reported that overexpression of transcription factors that activate the Arabidopsis high affinity transporter, HAK5, enhances tolerance to $\mathrm{K}^{+}$deficiency. In some cases, however, plants overexpressing $\mathrm{K}^{+}$transporters or upstream components of high affinity $\mathrm{K}^{+}$uptake do not show increased $\mathrm{K}^{+}$uptake and accumulation even though they exhibit some growth enhancement or increased salt tolerance (Adams et al., 2014; Song et al., 2014). This may be due to a redundancy or tight regulation of the temporal and spatial expression of these proteins. This absence of an effect on $\mathrm{K}^{+}$uptake could perhaps be alleviated by the use of either root specific or $\mathrm{K}^{+}$deficiency induced promoters. In addition to enhancing $\mathrm{K}^{+}$uptake from the soil solution, improving $\mathrm{K}^{+}$translocation in planta would greatly contribute to $\mathrm{K}^{+}$use efficiency. The efficiency of phloem $\mathrm{K}^{+}$transport is directly linked to the rate of shoot growth which is dependent on adequate $\mathrm{K}^{+}$availability (Ache et al., 2001; Deeken et al., 2002; Martin et al., 1993). Arabidopsis SKOR mediates the first step of $\mathrm{K}^{+}$long distance movement from the root to the shoot (Liu et al., 2006). KAT2, AKT2/3 and KEAs are also involved in intracellular $\mathrm{K}^{+}$translocation (Adams and Shin, 2014; Deeken et al., 2003; Maser et al., 2001; Philippar et al., 2004; Yao et al., 1997). Regulating the expression of these genes in a coordinated manner may contribute to an improvement in $\mathrm{K}^{+}$use efficiency, however, the validity requires further studies.

Increasing mobility of $\mathrm{K}^{+}$in the soil

$\mathrm{K}^{+}$availability can be increased by enhancing $\mathrm{K}^{+}$mobility in the soil and the release of $\mathrm{K}^{+}$from non-exchangeable forms (Rengel and Damon, 2008). One factor that has a positive effect on $\mathrm{K}^{+}$mobility is root exudates. Plants release organic acids such as malic acid and tartaric acid which result in increased $\mathrm{K}^{+}$mobility in soil (Wang et al., 2000). Inoculation of plant roots with Bacillus spp. bacteria increases root exudates and maize plants has been reported to increase $\mathrm{K}^{+}$uptake and growth upon inoculation (Rengel and Damon, 2008; Sheng and He, 2006; Zhao et al., 2013). Thus, enrichment of beneficial microorganisms may also be a useful strategy for improving $\mathrm{K}^{+}$availability in soil.

Molecular breeding using $\mathrm{K}^{+}$-associated quantitative trait loci (QTLs)

Breeding efforts directed at improving yield have focused on improving nutrient use and uptake efficiency. $\mathrm{K}^{+}$uptake and utilization efficiency varies within crop species and root traits also have a significant impact on determining crop yields (White et al., 2013a; 2013b). Root hair associated traits have been shown to be linked to higher $P$ acquisition (Brown et al., 2013). Additionally, several shoot $\mathrm{K}^{+}$-accumulation-associated QTLs are located on chromosome 4 of Arabidopsis, which harbor KUP2, ATK2, KAT2 and TPK3 (White et al., 2010). These QTLs could be used in breeding programs utilizing marker assisted selection. Chao et al. (2013) also have reported that tetraploid Arabidopsis has higher $\mathrm{K}^{+}$accumulation than diploid or haploid Arabidopsis suggesting that ploidy level could also be a factor used to improve $\mathrm{K}^{+}$accumulation.

The ability to absorb $\mathrm{K}^{+}$from soil is a prerequisite for plant survival and the ability to efficiently absorb, transport, and utilize $\mathrm{K}^{+}$is directly linked to the quality and yield of crops. Therefore, improving $\mathrm{K}^{+}$uptake and use efficiency in plants is a major target in the development of new crop cultivars. In this review, the current knowledge of the molecular processes involved in $\mathrm{K}^{+}$uptake, translocation, and the responses to $\mathrm{K}^{+}$availability is summarized. Based on this information, four strategies for improving $\mathrm{K}^{+}$use efficiency in plants are suggested (Fig. 1). The first strategy is directed at increasing root volume in order to obtain a large root surface area that is in contact with the soil solution. This could be accomplished by utilizing and overexpressing transcription factors that are directly involved in root development. The second strategy aims to improve $\mathrm{K}^{+}$uptake/translocation by activating various components of the $\mathrm{K}^{+}$ uptake/transport system. The third strategy involves enhancing $\mathrm{K}^{+}$mobility in the soil. It is suggested that increasing root exudates, which contain organic acids, would increase exchangeable and soluble $\mathrm{K}^{+}$in the soil. Lastly, the fourth strategy focuses on the use of $\mathrm{K}^{+}$efficiency-associated QTLs in breeding programs. A complex set of interacting molecular networks involved in a variety of biochemical activities have a direct or indirect influence on $\mathrm{K}^{+}$efficiency in field grown plants. Combi- 
nation of the suggested strategies and knowledge on the interaction of the $\mathrm{K}^{+}$-related regulatory mechanisms with other regulatory networks might contribute to the development of new cultivars that could utilize macronutrients more efficiently under the conditions where the resources are limited.

\section{ACKNOWLEDGMENTS}

I would like to thank all of the colleagues, whose research contributed to this review, including those colleagues whose publications are not cited due to space limitations. I also thank Dr. Eri Adams (RIKEN CSRS) for valuable comments. This work was supported by a RIKEN interdisciplinary research fund.

\section{REFERENCES}

Ache, P., Becker, D., Ivashikina, N., Dietrich, P., Roelfsema, M.R., and Hedrich, R. (2000). GORK, a delayed outward rectifier expressed in guard cells of Arabidopsis thaliana, is a $\mathrm{K}^{+}$-selective, $\mathrm{K}^{+}$-sensing ion channel. FEBS Lett. 486, 93-98.

Ache, P., Becker, D., Deeken, R., Dreyer, I., Weber, H., Fromm, J., and Hedrich, R. (2001). VFK1, a Vicia faba $\mathrm{K}^{+}$channel involved in phloem unloading. Plant J. 27, 571-580.

Adams, E., and Shin, R. (2014). Transport, signaling, and homeostasis of potassium and sodium in plants. J. Integr. Plant Biol. 56, 231-249.

Adams, E., Diaz, C., Matsui, M., and Shin, R. (2014). Overexpression of a novel component induces HAK5 and enhances growth in Arabidopsis. ISRN Bot. 2014, Article ID 490252.

Ahn, S.J., Shin, R., and Schachtman, D.P. (2004). Expression of KT/KUP genes in Arabidopsis and the role of root hairs in $\mathrm{K}^{+}$uptake. Plant Physiol. 134, 1135-1145.

Amtmann, A., and Armengaud, P. (2007). The role of calcium sensor-interacting protein kinases in plant adaptation to potassiumdeficiency: new answers to old questions. Cell Res. 17, 483-485.

Amtmann, A., and Armengaud, P. (2009). Effects of N, P, K and S on metabolism: new knowledge gained from multi-level analysis. Curr. Opin. Plant Biol. 12, 275-283.

Amtmann, A., and Blatt, M.R. (2009). Regulation of macronutrient transport. New Phytol. 181, 35-52.

Amtmann, A., Hammond, J.P., Armengaud, P., and White, P.J. (2006). Nutrient sensing and signalling in plants: Potassium and phosphorus. Adv. Bot. Res. 43, 209-257.

Aranda-Sicilia, M.N., Cagnac, O., Chanroj, S., Sze, H., RodriguezRosales, M.P., and Venema, K. (2012). Arabidopsis KEA2, a homolog of bacterial KefC, encodes a $\mathrm{K}^{+} / \mathrm{H}^{+}$antiporter with a chloroplast transit peptide. Biochim. Biophys. Acta 1818, 23622371.

Armengaud, P., Breitling, R., and Amtmann, A. (2004). The potassium-dependent transcriptome of Arabidopsis reveals a prominent role of jasmonic acid in nutrient signaling. Plant Physiol. 136, 2556-2576.

Armengaud, P., Breitling, R., and Amtmann, A. (2010). Coronatineinsensitive 1 (COI1) mediates transcriptional responses of Arabidopsis thaliana to external potassium supply. Mol. Plant 3, 390-405.

Ashley, M.K., Grant, M., and Grabov, A. (2006). Plant responses to potassium deficiencies: a role for potassium transport proteins. $\mathrm{J}$. Exp. Bot. 57, 425-436.

Banuelos, M.A., Garciadeblas, B., Cubero, B., and RodriguezNavarro, A. (2002). Inventory and functional characterization of the HAK potassium transporters of rice. Plant Physiol. 130, 784795

Bassil, E., Coku, A., and Blumwald, E. (2012). Cellular ion homeostasis: emerging roles of intracellular $\mathrm{NHX} \mathrm{Na} / \mathrm{H}^{+}$antiporters in plant growth and development. J. Exp. Bot. 63, 5727-5740.

Becker, D., Hoth, S., Ache, P., Wenkel, S., Roelfsema, M.R., Meyerhoff, O., Hartung, W., and Hedrich, R. (2003). Regulation of the ABA-sensitive Arabidopsis potassium channel gene GORK in response to water stress. FEBS Lett. 554, 119-126.

Berthomieu, P., Conejero, G., Nublat, A., Brackenbury, W.J., Lambert, C., Savio, C., Uozumi, N., Oiki, S., Yamada, K., Cellier, F., et al. (2003). Functional analysis of AtHKT1 in Arabidopsis shows that $\mathrm{Na}^{+}$recirculation by the phloem is crucial for salt to- lerance. EMBO J. 22, 2004-2014.

Britto, D.T., and Kronzucker, H.J. (2008). Cellular mechanisms of potassium transport in plants. Physiol. Plant. 133, 637-650.

Brown, L.K., George, T.S., Dupuy, L.X., and White, P.J. (2013). A conceptual model of root hair ideotypes for future agricultural environments: what combination of traits should be targeted to cope with limited $P$ availability? Ann. Bot. 112, 317-330.

Cakmak, I. (2005). The role of potassium in alleviating detrimental effects of abiotic stresses in plants. J. Plant Nutr. Soil Sci. 168 521-530.

Cellier, F., Conejero, G., Ricaud, L., Luu, D.T., Lepetit, M., Gosti, F., and Casse, F. (2004). Characterization of AtCHX17, a member of the cation $/ \mathrm{H}^{+}$exchangers, $\mathrm{CHX}$ family, from Arabidopsis thaliana suggests a role in $\mathrm{K}^{+}$homeostasis. Plant $\mathrm{J}$. 39, 834-846.

Chao, D.Y., Dilkes, B., Luo, H., Douglas, A., Yakubova, E., Lahner, B., and Salt, D.E. (2013). Polyploids exhibit higher potassium uptake and salinity tolerance in Arabidopsis. Science 341, 658659.

Cherel, I., Michard, E., Platet, N., Mouline, K., Alcon, C., Sentenac, H., and Thibaud, J.B. (2002). Physical and functional interaction of the Arabidopsis $\mathrm{K}^{+}$channel AKT2 and phosphatase AtPP2CA Plant Cell 14, 1133-1146.

Collins, N.C., Thordal-Christensen, H., Lipka, V., Bau, S., Kombrink, E., Quu, J.L., Huckelhoven, R., Stein, M., Freialdenhoven, A. Somerville, S.C., et al. (2003). SNARE-protein-mediated disease resistance at the plant cell wall. Nature 425, 973-977.

Czempinski, K., Zimmermann, S., Ehrhardt, T., and Muller-Rober, B. (1997). New structure and function in plant $\mathrm{K}^{+}$channels: KCO1, an outward rectifier with a steep $\mathrm{Ca}^{2+}$ dependency. EMBO J. 16, 2565-2575.

Czempinski, K., Frachisse, J.M., Maurel, C., Barbier-Brygoo, H., and Mueller-Roeber, B. (2002). Vacuolar membrane localization of the Arabidopsis 'two-pore' $\mathrm{K}^{+}$channel KCO1. Plant J. 29, 809820.

Corratge-Faillie, C., Jabnoune, M., Zimmermann, S., Very, A.A., Fizames, C., and Sentenac, H. (2010). Potassium and sodium transport in non-animal cells: the Trk/Ktr/HKT transporter family. Cell. Mol. Life Sci. 67, 2511-2532.

Damas, J.M., Oliveira, A.S., Baptista, A.M., and Soares, C.M. (2011). Structural consequences of ATP hydrolysis on the ABC transporter NBD dimer: molecular dynamics studies of HlyB. Protein Sci. 20, 1220-1230.

Daram, P., Urbach, S., Gaymard, F., Sentenac, H., and Cherel, I. (1997). Tetramerization of the AKT1 plant potassium channel involves its C-terminal cytoplasmic domain. EMBO J. 16, 34553463.

Davenport, R.J., Munoz-Mayor, A., Jha, D., Essah, P.A., Rus, A., and Tester, M. (2007). The $\mathrm{Na}^{+}$transporter AtHKT1;1 controls retrieval of $\mathrm{Na}^{+}$from the xylem in Arabidopsis. Plant Cell Environ. 30, 497-507.

Dean, G., Casson, S., and Lindsey, K. (2004). KNAT6 gene of Arabidopsis is expressed in roots and is required for correct lateral root formation. Plant Mol. Biol. 54, 71-84.

Deeken, R., Geiger, D., Fromm, J., Koroleva, O., Ache, P., Langenfeld-Heyser, R., Sauer, N., May, S.T., and Hedrich, R. (2002) Loss of the AKT2/3 potassium channel affects sugar loading into the phloem of Arabidopsis. Planta 216, 334-344.

Deeken, R., Ivashikina, N., Czirjak, T., Philippar, K., Becker, D., Ache, P., and Hedrich, R. (2003). Tumour development in Arabidopsis thaliana involves the Shaker-like $\mathrm{K}^{+}$channels AKT1 and AKT2/3. Plant J. 34, 778-787.

Demidchik, V., Davenport, R.J., and Tester, M. (2002). Nonselective cation channels in plants. Annu. Rev. Plant Biol. 53, 67-107.

Desbrosses, G., Josefsson, C., Rigas, S., Hatzopoulos, P., and Dolan, L. (2003). AKT1 and TRH1 are required during root hair elongation in Arabidopsis. J. Exp. Bot. 54, 781-788.

Duby, G., Hosy, E., Fizames, C., Alcon, C., Costa, A., Sentenac, H., and Thibaud, J.B. (2008). AtKC1, a conditionally targeted Shaker-type subunit, regulates the activity of plant $\mathrm{K}^{+}$channels. Plant J. 53, 115-123.

Epstein, E., Rains, D.W., and Elzam, O.E. (1963). Resolution of dual mechanisms of potassium absorption by barley roots. Proc Natl. Acad. Sci. USA 49, 684-692.

Food and Agriculture Organization of the United Nations (2006). Fertilizer use by crop. FAO publications, Rome, Italy.

Frietsch, S., Wang, Y.F., Sladek, C., Poulsen, L.R., Romanowsky, 
S.M., Schroeder, J.I., and Harper, J.F. (2007). A cyclic nucleotide-gated channel is essential for polarized tip growth of pollen. Proc. Natl. Acad. Sci. USA 104, 14531-14536.

Fu, H.H., and Luan, S. (1998). AtKuP1: a dual-affinity $\mathrm{K}^{+}$transporter from Arabidopsis. Plant Cell 10, 63-73.

Garciadeblas, B., Senn, M.E., Banuelos, M.A., and RodriguezNavarro, A. (2003). Sodium transport and HKT transporters: the rice model. Plant J. 34, 788-801.

Gattward, J.N., Almeida, A.A., Souza, J.O., Jr., Gomes, F.P., and Kronzucker, H.J. (2012). Sodium-potassium synergism in Theobroma cacao: stimulation of photosynthesis, water-use efficiency and mineral nutrition. Physiol. Plant. 146, 350-362.

Gaxiola, R.A., Rao, R., Sherman, A., Grisafi, P., Alper, S.L., and Fink, G.R. (1999). The Arabidopsis thaliana proton transporters, AtNhx1 and Avp1, can function in cation detoxification in yeast. Proc. Natl. Acad. Sci. USA 96, 1480-1485.

Geiger, D., Becker, D., Vosloh, D., Gambale, F., Palme, K., Rehers, M., Anschuetz, U., Dreyer, I., Kudla, J., and Hedrich, R. (2009). Heteromeric AtKC1 AKT1 channels in Arabidopsis roots facilitate growth under $\mathrm{K}^{+}$-limiting conditions. J. Biol. Chem. 284, 21288-21295.

Gierth, M., Maser, P., and Schroeder, J.I. (2005). The potassium transporter AtHAK5 functions in $\mathrm{K}^{+}$deprivation-induced highaffinity $\mathrm{K}^{+}$uptake and $\mathrm{AKT} 1 \mathrm{~K}^{+}$channel contribution to $\mathrm{K}^{+}$uptake kinetics in Arabidopsis roots. Plant Physiol. 137, 1105-1114.

Grabov, A. (2007). Plant KT/KUP/HAK potassium transporters: single family - multiple functions. Ann. Bot. 99, 1035-1041.

Guerrero-Mendiola, C., Oria-Hernandez, J., and Ramirez-Silva, L. (2009). Kinetics of the thermal inactivation and aggregate formation of rabbit muscle pyruvate kinase in the presence of trehalose. Arch. Biochem. Biophys. 490, 129-136.

Hao, J., Tu, L., Hu, H., Tan, J., Deng, F., Tang, W., Nie, Y., and Zhang, X. (2012). GbTCP, a cotton TCP transcription factor, confers fibre elongation and root hair development by a complex regulating system. J. Exp. Bot. 63, 6267-6281.

Hastings, D.F., and Gutknecht, J. (1978). Potassium and turgor pressure in plants. J. Theor. Biol. 73, 363-366.

Held, K., Pascaud, F., Eckert, C., Gajdanowicz, P., Hashimoto, K., Corratge-Faillie, C., Offenborn, J.N., Lacombe, B., Dreyer, I., Thibaud, J.B., et al. (2011). Calcium-dependent modulation and plasma membrane targeting of the AKT2 potassium channel by the CBL4/CIPK6 calcium sensor/protein kinase complex. Cell Res. 21, 1116-1130.

Hirsch, R.E., Lewis, B.D., Spalding, E.P., and Sussman, M.R. (1998). A role for the AKT1 potassium channel in plant nutrition. Science 280, 918-921.

Ho, C.H., Lin, S.H., Hu, H.C., and Tsay, Y.F. (2009). CHL1 functions as a nitrate sensor in plants. Cell 138, 1184-1194.

Hogh-Jensen, H., and Pedersen, M.B. (2003). Morphological plasticity by crop plants and their potassium use efficiency. J. Plant Nutr. 26, 969-984.

Holzmueller, E.J., Jose, S., and Jenkins, M.A. (2007). Influence of calcium, potassium, and magnesium on Cornus florida $\mathrm{L}$. density and resistance to dogwood anthracnose. Plant Soil 290, 189199

Hong, J.P., Takeshi, Y., Kondou, Y., Schachtman, D.P., Matsui, M., and Shin, R. (2013). Identification and characterization of transcription factors regulating Arabidopsis HAK5. Plant Cell Physiol. $54,1478-1490$

Honsbein, A., Sokolovski, S., Grefen, C., Campanoni, P., Pratelli, R., Paneque, M., Chen, Z., Johansson, I., and Blatt, M.R. (2009). A tripartite SNARE- $\mathrm{K}^{+}$channel complex mediates in channeldependent $\mathrm{K}^{+}$nutrition in Arabidopsis. Plant Cell 21, 2859-2877.

Horie, T., Yoshida, K., Nakayama, H., Yamada, K., Oiki, S., and Shinmyo, A. (2001). Two types of HKT transporters with different properties of $\mathrm{Na}^{+}$and $\mathrm{K}^{+}$transport in Oryza sativa. Plant $\mathrm{J}$. 27, 129-138.

Horie, T., Costa, A., Kim, T.H., Han, M.J., Horie, R., Leung, H.Y., Miyao, A., Hirochika, H., An, G., and Schroeder, J.I. (2007). Rice OsHKT2;1 transporter mediates large $\mathrm{Na}^{+}$influx component into $\mathrm{K}^{+}$-starved roots for growth. EMBO J. 26, 3003-3014.

Hwang, H., Yoon, J., Kim, H.Y., Min, M.K., Kim, J.A., Choi, E.H., Lan, W., Bae, Y.M., Luan, S., Cho, H., et al. (2013a). Unique features of two potassium channels, OsKAT2 and OsKAT3, expressed in rice guard cells. PLoS One 8, e72541.

Hwang, H., Yoon, J.Y., Cho, H., and Kim, B.G. (2013b). OsKAT2 is the prevailing functional inward rectifier potassium channels in rice guard cell. Plant Signal. Behav. 8, e26643.

Ivashikina, N., Becker, D., Ache, P., Meyerhoff, O., Felle, H.H., and Hedrich, R. (2001). $\mathrm{K}^{+}$channel profile and electrical properties of Arabidopsis root hairs. FEBS Lett. 508, 463-469.

Ivashikina, N., Deeken, R., Fischer, S., Ache, P., and Hedrich, R (2005). AKT2/3 subunits render guard cell $\mathrm{K}^{+}$channels $\mathrm{Ca}^{2+}$ sensitive. J. Gen. Physiol. 125, 483-492.

Jeanguenin, L., Alcon, C., Duby, G., Boeglin, M., Cherel, I., Gaillard, I., Zimmermann, S., Sentenac, H., and Very, A.A. (2011). AtKC1 is a general modulator of Arabidopsis inward Shaker channel activity. Plant J. 67, 570-582.

Jung, J.Y., Shin, R., and Schachtman, D.P. (2009). Ethylene mediates response and tolerance to potassium deprivation in Arabidopsis. Plant Cell 21, 607-621.

Kim, M.J., Shin, R., and Schachtman, D.P. (2009). A nuclear factor regulates abscisic acid responses in Arabidopsis. Plant Physiol. 151, 1433-1445.

Kim, M.J., Ciani, S., and Schachtman, D.P. (2010). A peroxidase contributes to ROS production during Arabidopsis root response to potassium deficiency. Mol. Plant 3, 420-427.

Kim, M.J., Ruzicka, D., Shin, R., and Schachtman, D.P. (2012). The Arabidopsis AP2/ERF transcription factor RAP2.11 modulates plant response to low-potassium conditions. Mol. Plant 5, 10421057.

Kirik, V., Simon, M., Huelskamp, M., and Schiefelbein, J. (2004). The ENHANCER OF TRY AND CPC1 gene acts redundantly with TRIPTYCHON and CAPRICE in trichome and root hair cell patterning in Arabidopsis. Dev. Biol. 268, 506-513.

Kudla, J., Xu, Q., Harter, K., Gruissem, W., and Luan, S. (1999). Genes for calcineurin B-like proteins in Arabidopsis are differentially regulated by stress signals. Proc. Natl. Acad. Sci. USA 96, 4718-4723.

Lacombe, B., Becker, D., Hedrich, R., DeSalle, R., Hollmann, M., Kwak, J.M., Schroeder, J.I., Le Novere, N., Nam, H.G., Spalding E.P., et al. (2001). The identity of plant glutamate receptors. Science 292, 1486-1487.

Lan, W.Z., Lee, S.C., Che, Y.F., Jiang, Y.Q., and Luan, S. (2011). Mechanistic analysis of AKT1 regulation by the CBL-CIPKPP2CA interactions. Mol. Plant 4, 527-536.

Latz, A., Becker, D., Hekman, M., Muller, T., Beyhl, D., Marten, I., Eing, C., Fischer, A., Dunkel, M., Bertl, A., et al. (2007). TPK1, a $\mathrm{Ca}^{2+}$-regulated Arabidopsis vacuole two-pore $\mathrm{K}^{+}$channel is activated by 14-3-3 proteins. Plant J. 52, 449-459.

Lebaudy, A., Pascaud, F., Very, A.A., Alcon, C., Dreyer, I., Thibaud, J.B., and Lacombe, B. (2010). Preferential KAT1-KAT2 heteromerization determines inward $\mathrm{K}^{+}$current properties in Arabidop sis guard cells. J. Biol. Chem. 285, 6265-6274.

Leigh, R.A., and Wyn Jones, R.G. (1984). A hypothesis relating critical potassium concentrations for growth to the distribution and function of this ion in the plant cell. New Phytol. 97, 1-13.

Leng, Q., Mercier, R.W., Yao, W., and Berkowitz, G.A. (1999). Cloning and first functional characterization of a plant cyclic nucleotide-gated cation channel. Plant Physiol. 121, 753-761.

Leng, Q., Mercier, R.W., Hua, B.G., Fromm, H., and Berkowitz, G.A (2002). Electrophysiological analysis of cloned cyclic nucleotidegated ion channels. Plant Physiol. 128, 400-410.

Leung, Y.M., Kwan, E.P., Ng, B., Kang, Y., and Gaisano, H.Y. (2007). SNAREing voltage-gated $\mathrm{K}^{+}$and ATP-sensitive $\mathrm{K}^{+}$ channels: tuning beta-cell excitability with syntaxin-1A and other exocytotic proteins. Endocr. Rev. 28, 653-663.

Leyman, B., Geelen, D., Quintero, F.J., and Blatt, M.R. (1999). A tobacco syntaxin with a role in hormonal control of guard cell ion channels. Science $283,537-540$.

Liesche, J., Schulz, A., Krugel, U., Grimm, B., and Kuhn, C. (2008). Dimerization and endocytosis of the sucrose transporter StSUT1 in mature sieve elements. Plant Signal. Behav. 3, 1136-1137.

Liu, K., Li, L., and Luan, S. (2006). Intracellular $\mathrm{K}^{+}$sensing of SKOR a Shaker-type $\mathrm{K}^{+}$channel from Arabidopsis. Plant J. 46, 260-268.

Liu, H., Tang, R., Zhang, Y., Wang, C., Lv, Q., Gao, X., Li, W., and Zhang, $\mathrm{H}$. (2010). AtNHX3 is a vacuolar $\mathrm{K}^{+} / \mathrm{H}^{+}$antiporter required for low-potassium tolerance in Arabidopsis thaliana. Plant Cell Environ. 33, 1989-1999.

Liu, L.L., Ren, H.M., Chen, L.Q., Wang, Y., and Wu, W.H. (2013). A protein kinase, calcineurin B-like protein-interacting protein kinase9, interacts with calcium sensor calcineurin B-like protein3 
and regulates potassium homeostasis under low-potassium stress in Arabidopsis. Plant Physiol. 161, 266-277.

Lu, Y.X., Chanroj, S., Zulkifli, L., Johnson, M.A., Uozumi, N., Cheung, A., and Sze, H. (2011). Pollen tubes lacking a pair of $\mathrm{K}^{+}$transporters fail to target ovules in Arabidopsis. Plant Cell 23, 81-93.

Luan, S., Lan, W., and Lee, S.C. (2009). Potassium nutrition, sodium toxicity, and calcium signaling:connections through the CBL-CIPK network. Curr. Opin. Plant Biol. 12, 339-346.

Ma, W., Ali, R., and Berkowitz, G.A. (2006). Characterization of plant phenotypes associated with loss-of-function of AtCNGC1, a plant cyclic nucleotide gated cation channel. Plant Physiol. Biochem. 44, 494-505.

Maathuis, F.J., and Sanders, D. (1992). Plant membrane transport. Curr. Opin. Cell Biol. 4, 661-669.

Martin, T., Frommer, W.B., Salanoubat, M., and Willmitzer, L. (1993). Expression of an Arabidopsis sucrose synthase gene indicates a role in metabolization of sucrose both during phloem loading and in sink organs. Plant J. 4, 367-377.

Maser, P., Thomine, S., Schroeder, J.I., Ward, J.M., Hirschi, K., Sze, H., Talke, I.N., Amtmann, A., Maathuis, F.J.M., Sanders, D., et al. (2001). Phylogenetic relationships within cation transporter families of Arabidopsis. Plant Physiol. 126, 1646-1667.

Maser, P., Hosoo, Y., Goshima, S., Horie, T., Eckelman, B., Yamada, K., Yoshida, K., Bakker, E.P., Shinmyo, A., Oiki, S., et al. (2002). Glycine residues in potassium channel-like selectivity filters determine potassium selectivity in four-loop-per-subunit HKT transporters from plants. Proc. Natl. Acad. Sci. USA 99, 6428-6433.

Montiel, G., Gantet, P., Jay-Allemand, C., and Breton, C. (2004). Transcription factor networks. Pathways to the knowledge of root development. Plant Physiol. 136, 3478-3485.

Morcuende, R., Bari, R., Gibon, Y., Zheng, W., Pant, B.D., Blasing, O., Usadel, B., Czechowski, T., Udvardi, M.K., Stitt, M., et al. (2007). Genome-wide reprogramming of metabolism and regulatory networks of Arabidopsis in response to phosphorus. Plant Cell Environ. 30, 85-112.

Mottaleb, S.A., Rodriguez-Navarro, A., and Haro, R. (2013). Knockouts of Physcomitrella patens $\mathrm{CHX} 1$ and $\mathrm{CHX} 2$ transporters reveal high complexity of potassium homeostasis. Plant Cell Physiol. 54, 1455-1468.

Nam, Y.J., Tran, L.S., Kojima, M., Sakakibara, H., Nishiyama, R., and Shin, R. (2012). Regulatory roles of cytokinins and cytokinin signaling in response to potassium deficiency in Arabidopsis. PLoS One 7, e47797.

Nieves-Cordones, M., Aleman, F., Martinez, V., and Rubio, F. (2010). The Arabidopsis thaliana HAK5 $\mathrm{K}^{+}$transporter is required for plant growth and $\mathrm{K}^{+}$acquisition from low $\mathrm{K}^{+}$solutions under saline conditions. Mol. Plant 3, 326-333.

Oecking, C., and Jaspert, N. (2009). Plant 14-3-3 proteins catch up with their mammalian orthologs. Curr. Opin. Plant Biol. 12, 760 765

Oria-Hernandez, J., Cabrera, N., Perez-Montfort, R., and RamirezSilva, L. (2005). Pyruvate kinase revisited: the activating effect of $\mathrm{K}^{+.}$J. Biol. Chem. 280, 37924-37929

Oria-Hernandez, J., Riveros-Rosas, H., and Ramirez-Silva, L. (2006). Dichotomic phylogenetic tree of the pyruvate kinase family: $\mathrm{K}^{+}$-dependent and -independent enzymes. J. Biol. Chem 281, 30717-30724.

Padmanaban, S., Chanroj, S., Kwak, J.M., Li, X., Ward, J.M., and Sze, H. (2007). Participation of endomembrane cation $/ \mathrm{H}^{+}$exchanger AtCHX20 in osmoregulation of guard cells. Plant Physiol. 144, 82-93.

Pajonk, S., Kwon, C., Clemens, N., Panstruga, R., and SchulzeLefert, P. (2008). Activity determinants and functional specialization of Arabidopsis PEN1 syntaxin in innate immunity. J. Biol. Chem. 283, 26974-26984.

Pettogrew, W.T. (2008). Potassium influences on yield and quality production for maize, wheat, soybean and cotton. Physiol. Plant. $133,670-681$

Philippar, K., Ivashikina, N., Ache, P., Christian, M., Luthen, H., Palme, K., and Hedrich, R. (2004). Auxin activates KAT1 and KAT2, two $\mathrm{K}^{+}$-channel genes expressed in seedlings of Arabidopsis thaliana. Plant J. 37, 815-827.

Philippar, K., Buchsenschutz, K., Edwards, D., Loffler, J., Luthen, H., Kranz, E., Edwards, K.J., and Hedrich, R. (2006). The auxin- induced $\mathrm{K}^{+}$channel gene $\mathrm{Zmk} 1$ in maize functions in coleoptile growth and is required for embryo development. Plant Mol. Biol. $61,757-768$

Pilot, G., Lacombe, B., Gaymard, F., Cherel, I., Boucherez, J., Thibaud, J.B., and Sentenac, H. (2001). Guard cell inward K channel activity in Arabidopsis involves expression of the twin channel subunits KAT1 and KAT2. J. Biol. Chem. 276, 32153221.

Qi, Z., and Spalding, E.P. (2004). Protection of plasma membrane $\mathrm{K}^{+}$transport by the salt overly sensitive $1 \mathrm{Na}^{+}-\mathrm{H}^{+}$antiporter during salinity stress. Plant Physiol. 136, 2548-2555.

Qi, Z., Hampton, C.R., Shin, R., Barkla, B.J., White, P.J., and Schachtman, D.P. (2008). The high affinity $\mathrm{K}^{+}$transporter AtHAK5 plays a physiological role in planta at very low $\mathrm{K}^{+}$concentrations and provides a caesium uptake pathway in Arabidopsis. J. Exp. Bot. 59, 595-607.

Rajan, S., Preisig-Muller, R., Wischmeyer, E., Nehring, R., Hanley, P.J., Renigunta, V., Musset, B., Schlichthorl, G., Derst, C., Karschin, A., et al. (2002). Interaction with 14-3-3 proteins promotes functional expression of the potassium channels TASK-1 and TASK-3. J. Physiol. 545, 13-26.

Ramirez-Silva, L., and Oria-Hernandez, J. (2003). Selectivity of pyruvate kinase for $\mathrm{Na}^{+}$and $\mathrm{K}^{+}$in water/dimethylsulfoxide mixtures. Eur. J. Biochem. 270, 2377-2385.

Ramirez-Silva, L., de Gomez-Puyou, M.T., and Gomez-Puyou, A (1993). Water-induced transitions in the $\mathrm{K}^{+}$requirements for the activity of pyruvate kinase entrapped in reverse micelles. Biochemistry 32, 5332-5338.

Ramirez-Silva, L., Ferreira, S.T., Nowak, T., Tuena de GomezPuyou, M., and Gomez-Puyou, A. (2001). Dimethylsulfoxide promotes $\mathrm{K}^{+}$-independent activity of pyruvate kinase and the acquisition of the active catalytic conformation. Eur. J. Biochem. 268, 3267-3274.

Ren, X.L., Qi, G.N., Feng, H.Q., Zhao, S., Zhao, S.S., Wang, Y., and Wu, W.H. (2013). Calcineurin B-like protein CBL10 directly interacts with AKT1 and modulates $\mathrm{K}^{+}$homeostasis in Arabidop sis. Plant J. 74, 258-266.

Rengel, Z., and Damon, P.M. (2008). Crops and genotypes differ in efficiency of potassium uptake and use. Physiol. Plant. 133 624-636.

Rigas, S., Debrosses, G., Haralampidis, K., Vicente-Agullo, F., Feldmann, K.A., Grabov, A., Dolan, L., and Hatzopoulos, P (2001). TRH1 encodes a potassium transporter required for tip growth in Arabidopsis root hairs. Plant Cell 13, 139-151.

Roberts, M.R. (2003). 14-3-3 proteins find new partners in plant cell signalling. Trends Plant Sci. 8, 218-223.

Rodriguez-Rosales, M.P., Galvez, F.J., Huertas, R., Aranda, M.N., Baghour, M., Cagnac, O., and Venema, K. (2009). Plant NHX cation/proton antiporters. Plant Signal. Behav. 4, 265-276.

Ros, R., Lemaillet, G., Fonrouge, A.G., Daram, P., Enjuto, M., Salmon, J.M., Thibaud, J.B., and Sentenac, H. (1999). Molecular determinants of the Arabidopsis AKT1 $\mathrm{K}^{+}$channel ionic selectivity investigated by expression in yeast of randomly mutated channels. Physiol. Plant. 105, 459-468.

Roy, S.J., Gilliham, M., Berger, B., Essah, P.A., Cheffings, C., Miller A.J., Davenport, R.J., Liu, L.H., Skynner, M.J., Davies, J.M., et al. (2008). Investigating glutamate receptor-like gene coexpression in Arabidopsis thaliana. Plant Cell Environ. 31, 861871

Rubio, F., Santa-Maria, G.E., and Rodriguez-Navarro, A. (2000). Cloning of Arabidopsis and barley cDNAs encoding HAK potassium transporters in root and shoot cells. Physiol. Plant. 109, 3443.

Santa-Maria, G.E., Rubio, F., Dubcovsky, J., and RodriguezNavarro, A. (1997). The HAK1 gene of barley is a member of a large gene family and encodes a high-affinity potassium transporter. Plant Cell 9, 2281-2289.

Sarwar, M. (2012). Effects of potassium fertilization on population build up of rice stem borers (lepidopteron pests) and rice (Oryza sativa L.) yield. J. Cereals Oilseeds 3, 6-9.

Sato, A., Sato, Y., Fukao, Y., Fujiwara, M., Umezawa, T., Shinozaki K., Hibi, T., Taniguchi, M., Miyake, H., Goto, D.B., et al. (2009) Threonine at position 306 of the KAT1 potassium channel is essential for channel activity and is a target site for ABA-activated SnRK2/OST1/SnRK2.6 protein kinase. Biochem. J. 424, 439448. 
Schachtman, D.P., and Shin, R. (2007). Nutrient sensing and signaling: NPKS. Annu. Rev. Plant Biol. 58, 47-69.

Schachtman, D.P., Schroeder, J.I., Lucas, W.J., Anderson, J.A., and Gaber, R.F. (1992). Expression of an inward-rectifying potassium channel by the Arabidopsis KAT1 cDNA. Science 258, 1654-1658

Schellmann, S., Schnittger, A., Kirik, V., Wada, T., Okada, K., Beermann, A., Thumfahrt, J., Jurgens, G., and Hulskamp, M. (2002). TRIPTYCHON and CAPRICE mediate lateral inhibition during trichome and root hair patterning in Arabidopsis. EMBO J. 21, 5036-5046.

Shabala, S., and Cuin, T.A. (2008). Potassium transport and plant salt tolerance. Physiol. Plant. 133, 651-669.

Shabala, S., Demidchik, V., Shabala, L., Cuin, T.A., Smith, S.J., Miller, A.J., Davies, J.M., and Newman, I.A. (2006). Extracellular $\mathrm{Ca}^{2+}$ ameliorates $\mathrm{NaCl}$-induced $\mathrm{K}^{+}$loss from Arabidopsis root and leaf cells by controlling plasma membrane $\mathrm{K}^{+}$-permeable channels. Plant Physiol. 141, 1653-1665.

Sheng, X.F., and He, L.Y. (2006). Solubilization of potassiumbearing minerals by a wild-type strain of Bacillus edaphicus and its mutants and increased potassium uptake by wheat. Can. J. Microbiol. 52, 66-72.

Shi, H., Ye, T., Chen, F., Cheng, Z., Wang, Y., Yang, P., Zhang, Y., and Chan, $Z$. (2013). Manipulation of arginase expression modulates abiotic stress tolerance in Arabidopsis: effect on arginine metabolism and ROS accumulation. J. Exp. Bot. 64, 1367-1379.

Shin, R. (2011). Transcriptional regulatory components responding to macronutrient limitation. J. Plant Biol. 54, 286-293.

Shin, R., and Schachtman, D.P. (2004). Hydrogen peroxide mediates plant root cell response to nutrient deprivation. Proc. Natl. Acad. Sci. USA 101, 8827-8832.

Shin, R., Berg, R.H., and Schachtman, D.P. (2005). Reactive oxygen species and root hairs in Arabidopsis root response to nitrogen, phosphorus and potassium deficiency. Plant Cell Physiol. 46, 1350-1357.

Shin, R., Burch, A.Y., Huppert, K.A., Tiwari, S.B., Murphy, A.S., Guilfoyle, T.J., and Schachtman, D.P. (2007). The Arabidopsis transcription factor MYB77 modulates auxin signal transduction. Plant Cell 19, 2440-2453.

Shin, R., Jez, J.M., Basra, A., Zhang, B., and Schachtman, D.P. (2011). 14-3-3 proteins fine-tune plant nutrient metabolism. FEBS Lett. 585, 143-147.

Sokolovski, S., Hills, A., Gay, R.A., and Blatt, M.R. (2008). Functional interaction of the SNARE protein NtSyp121 in $\mathrm{Ca}^{2+}$ channel gating, $\mathrm{Ca}^{2+}$ transients and ABA signalling of stomatal guard cells. Mol. Plant 1, 347-358

Song, Z., Yang, S., Zhu, H., Jin, M., and Su, Y. (2014). Heterologous expression of an alligatorweed high-affinity potassium transporter gene enhances salinity tolerance in Arabidopsis thaliana. Am. J. Bot. 101, 840-850

Sottocornola, B., Visconti, S., Orsi, S., Gazzarrini, S., Giacometti, S., Olivari, C., Camoni, L., Aducci, P., Marra, M., Abenavoli, A., et al. (2006). The potassium channel KAT1 is activated by plant and animal 14-3-3 proteins. J. Biol. Chem. 281, 35735-35741.

Sottocornola, B., Gazzarrini, S., Olivari, C., Romani, G., Valbuzzi, P., Thiel, G., and Moroni, A. (2008). 14-3-3 proteins regulate the potassium channel KAT1 by dual modes. Plant Biol. 10, 231-236.

Spalding, E.P., Hirsch, R.E., Lewis, D.R., Qi, Z., Sussman, M.R., and Lewis, B.D. (1999). Potassium uptake supporting plant growth in the absence of AKT1 channel activity: Inhibition by ammonium and stimulation by sodium. J. Gen. Physiol. 113, 909-918.

Sun, J., Bankston, J.R., Payandeh, J., Hinds, T.R., Zagotta, W.N., and Zheng, N. (2014). Crystal structure of the plant dual-affinity nitrate transporter NRT1.1. Nature 507, 73-77.

Sutter, J.U., Campanoni, P., Tyrrell, M., and Blatt, M.R. (2006). Selective mobility and sensitivity to SNAREs is exhibited by the Arabidopsis $\mathrm{KAT} 1 \mathrm{~K}^{+}$channel at the plasma membrane. Plant Cell 18, 935-954.

Sutter, J.U., Sieben, C., Hartel, A., Eisenach, C., Thiel, G., and Blatt, M.R. (2007). Abscisic acid triggers the endocytosis of the Arabidopsis $\mathrm{KAT} 1 \mathrm{~K}^{+}$channel and its recycling to the plasma membrane. Curr. Biol. 17, 1396-1402.

Syers, J.K. (1998). Soil and plant potassium in agriculture. York: The Fertilzer Society

Szczerba, M.W., Britto, D.T., Ali, S.A., Balkos, K.D., and Kronzuck- er, H.J. (2008). $\mathrm{NH}_{4}{ }^{+}$-stimulated and -inhibited components of $\mathrm{K}^{+}$ transport in rice (Oryza sativa L.). J. Exp. Bot. 59, 3415-3423.

Tapken, D., and Hollmann, M. (2008). Arabidopsis thaliana glutamate receptor ion channel function demonstrated by ion pore transplantation. J. Mol. Biol. 383, 36-48.

Tominaga-Wada, R., Iwata, M., Nukumizu, Y., Sano, R., and Wada, T. (2012). A full-length R-like basic-helix-loop-helix transcription factor is required for anthocyanin upregulation whereas the $\mathrm{N}$ terminal region regulates epidermal hair formation. Plant Sci. 183, 115-122.

Tsay, Y.F., Ho, C.H., Chen, H.Y., and Lin, S.H. (2011). Integration of nitrogen and potassium signaling. Annu. Rev. Plant Biol. 62 , 207-226.

Very, A.A., and Sentenac, H. (2003). Molecular mechanisms and regulation of $\mathrm{K}^{+}$transport in higher plants. Annu. Rev. Plant Biol. $54,575-603$

Vicente-Agullo, F., Rigas, S., Desbrosses, G., Dolan, L., Hatzopoulos, P., and Grabov, A. (2004). Potassium carrier TRH1 is required for auxin transport in Arabidopsis roots. Plant J. 40, 523535.

Voelker, C., Schmidt, D., Mueller-Roeber, B., and Czempinski, K. (2006). Members of the Arabidopsis AtTPK/KCO family form homomeric vacuolar channels in planta. Plant J. 48, 296-306.

Wada, T., Kurata, T., Tominaga, R., Koshino-Kimura, Y., Tachibana, T., Goto, K., Marks, M.D., Shimura, Y., and Okada, K. (2002). Role of a positive regulator of root hair development, CAPRICE, in Arabidopsis root epidermal cell differentiation. Development 129, 5409-5419.

Walker, D.J., Leigh, R.A., and Miller, A.J. (1996). Potassium homeostasis in vacuolate plant cells. Proc. Natl. Acad. Sci. USA 93, 10510-10514.

Wang, Y., and Wu, W.H. (2010). Plant sensing and signaling in response to $\mathrm{K}^{+}$-deficiency. Mol. Plant 3, 280-287.

Wang, Y., and Wu, W.H. (2013). Potassium transport and signaling in higher plants. Annu. Rev. Plant Biol. 64, 451-476.

Wang, J.G., Zhang, F.S., Zhang, X.L., and Cao, Y.P. (2000). Release of potassium from K-bearing minerals:effect of plant roots under $\mathrm{P}$ deficiency. Nutr. Cycl. Agroecosyst. 56, 45-52.

Wang, M., Zheng, Q., Shen, Q., and Guo, S. (2013). The critical role of potassium in plant stress response. Int. J. Mol. Sci. 14 7370-7390.

White, P.J., Hammond, J.P., King, G.J., Bowen, H.C., Hayden, R.M., Meacham, M.C., Spracklen, W.P., and Broadley, M.R. (2010). Genetic analysis of potassium use efficiency in Brassica oleracea. Ann. Bot. 105, 1199-1210.

White, P.J., George, T.S., Dupuy, L.X., Karley, A.J., Valentine, T.A., Wiesel, L., and Wishart, J. (2013a). Root traits for infertile soils. Front Plant Sci. 4, 193

White, P.J., George, T.S., Gregory, P.J., Bengough, A.G., Hallett, P.D., and McKenzie, B.M. (2013b). Matching roots to their environment. Ann. Bot. 112, 207-222.

Williams, J., and Smith, S.G. (2001). Correcting potassium deficiency can reduce rice stem disease. Better crops $85,7-9$.

Xie, Q., Frugis, G., Colgan, D., and Chua, N.H. (2000). Arabidopsis NAC1 transduces auxin signal downstream of TIR1 to promote lateral root development. Genes Dev. 14, 3024-3036.

Xu, W.F., and Shi, W.M. (2006). Expression profiling of the 14-3-3 gene family in response to salt stress and potassium and iron deficiencies in young tomato (Solanum lycopersicum) roots: analysis by real-time RT-PCR. Ann. Bot. 98, 965-974.

$\mathrm{Xu}$, J., Li, H.D., Chen, L.Q., Wang, Y., Liu, L.L., He, L., and Wu, W.H. (2006). A protein kinase, interacting with two calcineurin Blike proteins, regulates $\mathrm{K}^{+}$transporter AKT1 in Arabidopsis. Cell $125,1347-1360$

Yao, W., Hadjeb, N., and Berkowitz, G.A. (1997). Molecular cloning and characterization of the first plant $\mathrm{K}(\mathrm{Na}) /$ proton antiporter. Plant Physiol. 114S, 200.

Yong, Z., Kotur, Z., and Glass, A.D. (2010). Characterization of an intact two-component high-affinity nitrate transporter from Arabidopsis roots. Plant J. 63, 739-748.

Zhang, H.M., and Forde, B.G. (1998). An Arabidopsis MADS box gene that controls nutrient-induced changes in root architecture. Science 279, 407-409.

Zhao, J., Cheng, N.H., Motes, C.M., Blancaflor, E.B., Moore, M., Gonzales, N., Padmanaban, S., Sze, H., Ward, J.M., and Hirschi, K.D. (2008). AtCHX13 is a plasma membrane $\mathrm{K}^{+}$transporter. 
Plant Physiol. 148, 796-807.

Zhao, F., Guo, X.Q., Wang, P., He, L.Y., Huang, Z., and Sheng, X.F.

(2013). Dyella jiangningensis sp. nov., a gamma-proteobac terium isolated from the surface of potassium-bearing rock. Int. J. Syst. Evol. Microbiol. 63, 3154-3157. 